\title{
NÁSTROJ POSILŇOVANIA NÁRODNÉHO DUCHA? PODOBY MÚZEÍ NA SLOVENSKU V OBDOBÍ EXISTENCIE SLOVENSKÉHO ŠTÁTU
}

\author{
Miroslav Palárik
}

\section{Way of Strengthening the National Spirit? Forms of Museums in Slovakia during the Existence of the Slovak State}

Abstract: The aim of the paper is to describe the potential role of museums in spreading state ideology and propaganda. It furthermore attempts to answer the question of whether objects in Slovak museums could serve to strengthen love and devotion towards the State and nation, as well as encourage national awareness. The paper also focuses on exploring the extent to which the documentation of the present has been undertaken in the largest Slovak museums in Bratislava and Turčiansky Svätý Martin. Research was conducted in the Archives and in incremental books of these museums.

Keywords: Culture - Slovak State - museums - documentation of the present

Contact: Mgr. Miroslav Palárik, PhD.; Univerzita Konštantína Filozofa v Nitre, Filozofická fakulta, Katedra histórie; Hodžova 1, 949 01 Nitra, Slovensko; mpalarik@ukf.sk

Úvod

Medzinárodná kríza z konca 30. rokov 20. storočia naplno zasiahla do dejín medzivojnového Československa. ${ }^{1}$ Mníchovská dohoda, vyhlásenia autonómie Slovenska a Viedenská arbitráž spôsobili rozsiahle vnútropolitické i územné zmeny v krajine, ktorá bola označovaná ako ostrov demokracie v strednej Európe. Následný vývoj na Slovensku smeroval $\mathrm{k}$ presadeniu autoritatívneho režimu jednej politickej strany - Hlinkovej slovenskej l'udovej strany (od decembra 1938 s prídavkom - strana slovenskej národnej jednoty). Krátke, iba šest'mesačné obdobie trvania Česko-Slovenskej republiky, využili predstavitelia tejto politickej strany na výrazné obmedzenie občianskych a l'udských práv a to pod rúškom zjednocovania politického a národného života. ${ }^{2}$ V marci 1939 došlo pod tlakom Adolfa Hitlera k rozpadu Česko-Slovenskej republiky a vzniku Slovenského štátu a Protektorátu Čechy a Morava, ktorý sa stal súčast’ou ríše. Nastupujúca politická elita so sebou priniesla i vlastné predstavy o ideálnom fungovaní štátu, ktoré vychádzali z katolicizmu a boli obohatené o prvky nacistickej a fašistickej ideológie. ${ }^{3}$ Jej tvorcom bol Štefan Polakovič ${ }^{4}$. Dôraz sa začal klást' na presadzovanie nacionalizmu, antisemitizmu ( $\mathrm{v}$ akejkol'vek podobe), korporativizmu a totalitarizmu ( $\mathrm{v}$ zmysle uprednostňovania národa pred záujmami jednotlivca). ${ }^{5}$ Politickí reprezentanti mali isté predstavy i o umení a kultúre, ich podobe, limitoch a možnostiach vplyvu na občanov. Avšak, tak ako vo vládnej strane pretrvávali neustále konfrontácie medzi umierneným a radikálnym krídlom v názoroch na rôzne aspekty života v štáte, tak aj v kultúrnej oblasti sa prejavovala značná rozpoltenost' a ideový eklekticizmus. Vlasta Jaksicsová upozorňuje, že špecifikom režimu na Slovensku po marci 1939 bolo poskytnutie priestoru umelcom na prezentáciu názorov, ktoré sa nie vždy zhodovali s predstavami hlavnej politickej línie. Na rozdiel od nemeckého protektora, teda bola slovenskej politickej reprezentácii cudzia totalitná kontrola kultúry. ${ }^{6} \mathrm{~S}$ týmto tvrdením

\footnotetext{
Príspevok je čiastkovým výstupom projektov: APVV-17-0199: Kultúrny produkt regionálneho múzea v kontexte objektívnej spoločenskej potreby: Život v totalite v rokoch 1939-1945; KEGA č. 037UKF-4/2018: Nitra a nitriansky región v čase totality 1939-1945; VEGA č. 1/0093/18: Od demokracie k autoritárstvu. Zmeny slovenskej spoločnosti počas autonómie (1938-1939) na príklade Ponitria.

${ }^{2}$ K problematike vývoja v období autonómie Slovenska pozri napríklad: Valerián BYSTRICKÝ, Od autonómie k vzniku Slovenského štátu, Bratislava 2008; Róbert ARPÁŠ, Autonómia: vítazstvo alebo prehra? Vyvrcholenie politického zápasu HSL'S o autonómiu Slovenska, Bratislava 2011; Ján MITÁČ (ed.), Juh Slovenska po Viedenskej arbitráźi 1938-1945, Bratislava 2011; Valerián BYSTRICKÝ - Miroslav MICHELA - Michal SCHVARC a kol., Rozbitie alebo rozpad? Historické reflexie Česko-Slovenska, Bratislava 2010.

${ }^{3}$ K tomu pozri napríklad: Michaela LENČÉŠSVÁ, Comeback Štefana Polakoviča po vzniku Slovenskej republiky. K Polakovičovmu hl’adaniu zmyslu slovenských dejín 20. storočia, in: Milan BELEJ - Peter KERESTEŠ - Miroslav PALÁRIK (eds.), Míl’niky 20. storočia v regióne Nitrianskeho kraja, Nitra 2018, s. 214-227; Miloslav SZABÓ, Klérofašisti. Slovenskí kňazi a pokušenie radikálnej politiky (1935-1945), Bratislava 2019.

4 Štefan POLAKOVIČ, K základom Slovenského štátu. Filozofické eseje, Turčiansky Svätý Martin 1939; Martin PEKÁR, Štátna ideológia a jej vplyv na charakter režimu, in: Martina FIAMOVÁ - Ján HLAVINKA - Michal SCHVARC a kol., Slovenský štát 1939-1945: predstavy a realita, Bratislava 2014, s. 137-152; Anton HRUBOŇ, Slovenský národný socializmus v koncepciách Štefana Polakoviča a Stanislava Mečiara (Dva návrhy posalzburského smerovania prvej Slovenskej republiky), in: Anton HRUBON (ed.), Slovensko v rokoch neslobody $1938-1989$ II. Osobnosti známe - neznáme, Bratislava 2014, s. 20-34.

Porovnaj: M. PEKÁR, Štátna ideológia, s. 143

${ }^{6} \mathrm{~K}$ tomu pozri: Vlasta JAKSICSOVÁ, Kultúra v dejinách (Dejiny v kultúre), Bratislava 2012, s. 169 an.
} 
však nemožno úplne súhlasit'. Snahy o kontrolu a presadenie ideí vládnucej strany tu vždy boli, ako to častokrát ukazujú zákulisné informácie. ${ }^{7}$ Do vel'kej miery však záležalo na kontaktoch jednotlivcov, ich odvahe vzdorovat' i za cenu existenčných problémov a schopnostiach vyjadrit' svoj názor v náznakoch, inotajoch.

Kultúrno-osvetové a pamätové inštitúcie mali v systéme šŕrenia ideologických myšlienok zaujímat' popredné miesta. Úlohou malo byt šírenie ideí vládnej moci medzi l'ud'mi, vtláčanie pečate radikalizmu do širokých vrstiev spoločnosti a vytvorenie konformnej, sivej masy strane oddaných občanov. Bola to úloha značne náročná, vzhl'adom na vzdelanostnú, sociálnu, náboženskú, ideovú a národnostnú rozdielnost' obyvatel'ov republiky. Jednou z pamät'ových inštitúcií, ktoré mali byt' súčast'ou štátnej osvetovej mašinérie, bolo i múzeum. Táto inštitúcia bola v danom období stále verejnost'ou vnímaná ako chrám minulosti, slovami Miloša Řezníka a Martina Schulza Wessela „médium spomienkovej kultúry“68. V prípade šírenia národného príbehu vedúceho $\mathrm{k}$ úplnej národnej emancipácii mohli byt' teda ideálnymi ústavmi, ked’že opatrovali pamiatky minulosti. Väčšina múzeí sa však profilovala v 19. storočí v prostredí monarchie a zbierala pamiatky s ambíciou vytvárat' národný príbeh ${ }^{9}$ niekoho iného než Slovákov. ${ }^{10}$ Výnimku tvorilo múzeum v Turčianskom Svätom Martine a, samozrejme, ústavy založené po roku 1918. Z hl'adiska interpretácie histórie, ako upozorňuje Adam Hudek, poslúžila súdobým dejepiscom nová definícia slovenských dejín, založená na popise historických udalostí odohrávajúcich sa na „národnom území“ Slovákov, a tiež chápanie členov národa ako prostého slovenského l'udu ${ }^{11}$, ktoré priniesol František Hrušovský v syntéze slovenských dejín ${ }^{12}$. Národný príbeh bolo v období existencie Slovenskej republiky potrebné ukončit' v politikmi tol'kokrát zdôrazňovanom „samostatnom“ Slovenskom štáte. To však bol problém. Aby príbeh mohol byt' vo výstavnom priestore dokončený, bolo nutné koncentrovat' sa na dokumentáciu súčasnosti. Boli však na to múzeá pripravené? Na túto otázku nie je v súčasnosti možné jednoznačne odpovedat', nakol'ko výskum v tejto oblasti zatial' neprebehol. Príspevok je prvou sondou do problematiky dokumentácie súčasnosti v slovenských múzeách v období rokov 1939-1945. Ked’že vykonat' prieskum vo všetkých v danej dobe existujúcich múzeách by bolo značne náročné, sústredil som sa na sledovanie tohto typu dokumentácie v dvoch vtedy najväčších múzeách na Slovensku a to Slovenskom národnom múzeu v Turčianskom Svätom Martine a Slovenskom múzeu v Bratislave. V štúdii sa tiež pokúsim odpovedat' na nasledovné otázky: Boli slovenské múzeá schopné prevziat' úlohy šíritel'a národného príbehu a štátnej ideológie? Mala o ne väčšinová spoločnost' záujem? Aký bol ich význam pre rodiaci sa štát a novú politickú garnitúru? V príspevku sa tiež budem snažit' osvetlit' dôvody zmien v oblasti múzejníctva po marci 1939.

\section{Stručný náčrt vplyvu politickej moci na umeleckú tvorbu v období Slovenskej republiky}

Ciel'om predstavitel'ov Hlinkovej slovenskej l'udovej strany bolo, v duchu praktík autoritárskych a totalitných režimov, zglajchšaltovanie života obyvatel'ov Slovenska. Vzorom sa v mnohých oblastiach života stávalo nacistické Nemecko, ktoré sa šírením „Kulturpolitik“ v satelitných štátoch snažilo ovplyvnit' široké masy obyvatel'stva. Predpokladom na napíňanie týchto zámerov bolo podpísanie dohody o kultúrnej spolupráci, ktorej nosnou čast’ou bola výmena kultúrneho potenciálu s nemeckým protektorom. ${ }^{13}$ Snaha o propagáciu nemeckej kultúrnej tvorby na Slovensku zasiahla výstavnú, divadelnú, filmovú alebo hudobnú scénu ${ }^{14}$. Jednostranná orientácia slovenskej umeleckej tvorby a kultúry sa však nestretávala so všeobecným súhlasom zo strany odbornej verejnosti. Niektorí, hoci ich hlasy sa predstavitelia oficiálneho

7 Monika KAPRÁLIKOVÁ, Elán vo vojnovej Bratislave: podoba a okolnosti vydávania časopisu v rokoch 1939-1944, in: Slovenská literatúra, 2015 , roč. 62 , č. 1, s. $8-9$.

8 Miloš ŘEZNÍK - Martin SCHULZE WESSEL, Muzeum jako médium histoire croisée Nemců, Čechů a Slováků, in: Dušan KOVÁČ - Miloš ŘEZNÍK - Martin SCHULZE WESSEL (eds.), Muzealizace dějin v česko-nemecko-slovenském kontextu, Praha 2017, s. 14.

${ }^{9}$ K národnému príbehu pozri napríklad: Adam HUDEK, Najpolitickejšia veda. Slovenská historiografia 1948-1989, Bratislava 2010, s. 11 an.; László VÖRÖS, Analytická historiografia verzus národné dejiny. „, Národ“" ako sociálna reprezentácia, Pisa 2010, s. 3 an.; Zuzana HASAROVÁ, Nový sviatok v kalendári komunistického režimu. K formovaniu osláv československo-sovietskeho vzt’ahu na konci 40. rokov 20. storočia, in: Studia Historica Nitriensia, 2016, roč. 20, č. 1, s. 135-160.

${ }^{10}$ L’ubomír LIPTÁK, Múzeá a historiografia na Slovensku do roku 1918, in: Zborník Slovenského národného múzea, 1987, roč. 81, História - 27, s. 273-289; L’ubomír LIPTÁK, Múzeá a historiografia na Slovensku v rokoch 1918-1945, in: Zborník Slovenského národného múzea, 1989, roč. 83, História - 29, s. 209-225.

${ }^{11}$ Adam HUDEK, Historik František Hrušovský: žiak Václava Chaloupeckého ako tvorca l’udáckej koncepcie slovenských dejín, in: Milan DUCHÁČEK - Jitka BÍLKOVÁ a kol., Václav Chaloupecký a generace roku 1914:otazníky české a slovenské historiografie v éře první republiky, Liberec - Praha - Turnov 2018, s. 124.

${ }^{12}$ František HRUŠOVSKÝ, Slovenské dejiny, Turčiansky Svätý Martin 1939

${ }^{13}$ Stanislav DRAGÚŇ, Nemecko-slovenská dohoda z roku 1942 o spolupráci na kultúrnom poli a jej realizácia v praxi, Historický časopis, 2007, roč. 55, č. 3, s. 559-576; Michal SCHVARC - Ludovít HALLON, Nemecká kultúrna politika na Slovensku v rokoch 1939-1945. Náčrt problematiky, in: Peter SOKOLOVIČ (ed.), Život v Slovenskej republike - Slovenská republika 1939-1945 očami mladých historikov IX., Bratislava 2011, s. 259-284.

${ }^{14}$ Miroslav PALÁRIK, Sväz slovenských múzei v obdobi slovenského štátu 1939-1945, Nitra 2011; Vladimír ŠTEFKO, Slovenské činoherné divadlo 1938-1945: Pokus o načrtnutie problematiky, Bratislava 1993; Miroslav PALÁRIK, Divadelníctvo v Nitre v rokoch 1939-1945, Studia historica Nitriensia, 2017, roč. 21, č. 2, s. 366-430; Alena MIKULÁŠOVÁ - Miroslav PALÁRIK, Nitrianske kiná v období druhej svetovej vojny, Historický časopis, 2015, roč. 63, č. 2, s. 291-312; Petra HANÁKOVÁ, Udávat', dozerat' a trestat'. Slovenské kino 1939-1945 v policajných a iných archivoch, in: Martin KAŇUCH (ed.), Film a kultúrna pamät', Bratislava 2014, s. 114-127; Martin CIEL, Film a politika. Ideológia a propaganda v slovenskom filme 1939-1989, Bratislava 2017; Ivan KAMENEC, Kultúrne paradoxy vo vzt'ahoch medzi satelitom a vel'mocou. Slovenská kultúra pod nemeckým „, ochranným patronátom “, in: Ivan KAMENEC, Spoločnost', politika, historiografia. Pokrivené (?) zrkadlo dejín slovenskej spoločnosti v dvadsiatom storočí, Bratislava 2009, s. 119; Martin HETÉNYI, Niektoré aspekty kultúrnej, umeleckej a osvetovej činnosti mesta Nitra v rokoch 1939-1945, Konštantínove listy, 2015, roč. 8, č. 2, s. 78-87; Miroslav PALÁRIK - Alena MIKULÁŠOVÁ, Libri prohibiti. Zásahy politiky do knižnej produkcie a knižničných fondov počas druhej svetovej vojny na príklade mesta Nitra, Muzeológia a kultúrne dedičstvo, 2016, roč. 4 , č. 2, s. 117-137; Vladimír DRAXLER, Slovenský rozhlas 1938-1945, Acta Universitatis Carolinae - Studia territorialia, 2013, č. 1-2, s. 141-175. 
smerovania snažili prekričat', videli východisko v orientácii na viaceré krajiny, aby sa umelecká tvorba prejavila v celej jej košatosti. ${ }^{15}$ Priame nasledovanie myšlienok nacionálneho socializmu šíreného z nemeckej ríše chcela vládna moc presadit' aj prostredníctvom oficiálnych proklamácií čo najväčšieho počtu umelecky činných a známych osobností kultúrneho života. V tomto duchu bol spísaný tzv. Lomnický manifest v roku 1940. ${ }^{16}$ Predstavy vládnej moci o podobe slovenskej umeleckej tvorby sa snažili jej reprezentanti implantovat' do praxe aj rôznymi apelmi v časopisoch, ktoré kritizovali nezrozumitel'nost' diel niektorých slovenských umelcov, najmä tých, ktorí sa vydali „vlastnou cestou“. Požiadavkou doby bolo tvorit' diela všeobecne prístupné a najmä zrozumitel'né čo najširšiemu publiku, napíňajúce prísne ideologické kritériá mravnej čistoty a národnej hrdosti. Týkalo sa to najmä výtvarného umenia, kde sa dôraz kládol na „nábožensko-ideologický a politicko-didaktický rozmer diela“"17. Z literárnej tvorby pod zmienené tendencie spadala poézia. Snaha o umeleckost', invenciu a kreativitu, ktorá odlišovala jednotlivých autorov, bola vnímaná negatívne, pretože bola väčšinovému publiku údajne nezrozumitel'ná. ${ }^{18}$ Snahu o ovplyvňovanie umeleckej tvorby na Slovensku dokumentujú aj vyjadrenia literárneho historika a kritika Andreja Mráza v článku s názvom: Chápanie umenia, ktorý vyšiel v roku 1942 na stránkach časopisu Elán. Predmetná stat' je kritikou prijímatel'ov, ale aj „objednávatel'ov“" umenia, ktorí nemali jasnú predstavu o umení, nechápali ho v náležitých súvislostiach a neboli schopní vnímat' využitú symboliku umeleckého diela a napriek tomu: ,,... žiadali od nich lokajské služby. Čomu majú slúžit? Náročný zákonodarca neodpovie ti na takúto otázku. On len čosi počul, čosi počítal, akési heslovité výkriky udierali sa mu do uší, všetko to naplnilo ho ukrutným sebavedomím a dnes umelcom chce predpisovat'... netajme si, u nás je dnes vel'a ambícií nepovolaných zasahovat' do umení ... O pomýlenom postoji k umeniam dozvedáš sa často $v$ rozhovore s jednotlivcami, na divadelných predstaveniach, na koncertoch, na výstavách, pri počúvaní úsudkov o knihách a všade inde. ... no čitatel'skí, divadelní a ini umelecki horlivci neuspokojujú sa u nás hundraním po kútoch, v úzkom kruhu seberovných, oni idú aj na verejnost'. Raz im denné noviny dali možnost'v knižnej ankete hlasovat'o knihách, prečo by im teraz nedali možnost' na iný spôsob vynášat' úsudky o umení. "19 Vládna moc si našla aj v tejto sfére prisluhovačov, ktorí boli, za výhody zo strany štátu, ochotní plnit’ ideologické požiadavky „objednávatel'a“. Bola to však ,deravá totalita“"20 , ktorá síce chcela usmerňovat', ale nevedela ako a vlastne ani akým smerom. Úloha štátostrany v tomto prípade bola o to zložitejšia, že samotná umelecká sféra bola značne rozpoltená, lavírujúca medzi politikou, presvedčením a svedomím jednotlivých autorov. Samozrejme, existovala aj skupina umelcov, ktorí sa nepodvolili ideologickému dozoru a v tomto období sa radšej umelecky odmlčali. ${ }^{21}$

\section{Zmeny v múzejníctve a pamiatkovej starostlivosti po vzniku slovenského štátu}

Po vyhlásení Slovenského štátu 14. marca 1939 došlo na Slovensku k zásadnejším zmenám v oblasti starostlivosti o kultúrne pamiatky. Dovtedajšia dvojkol'ajnost' v pamiatkovej starostlivosti bola odstránená, pretože v zmysle vládneho nariadenia č. 29/1939 zo dňa 24. marca 1939 zanikol Štátny referát na ochranu pamiatok na Slovensku, respektíve sa stal súčast'ou Ministerstva školstva a národnej osvety v Bratislave (d'alej MŠANO). ${ }^{22}$ Pod zmienené ministerstvo spadali všetky záležitosti školstva, ochrany pamiatok, organizácie múzejníctva a archívnictva a tiež umenia, štátneho nakladatel'stva a kultov. ${ }^{23}$ Bolo aj najvyšším orgánom štátnej správy vo veciach kultúry a osvety verejného života. Jednotnému vedeniu boli podriadené všetky okresné a mestské osvetové komisie, ktoré spadali pod Ústrednú osvetovú komisiu pri MŠANO. Pod kuratelu týchto komisií patril dozor nad divadlami, kinematografiou a knižnicami. ${ }^{24} \mathrm{Na}$ ministerstve sa vytvoril systém odborov a príslušných pomocných úradov, ktoré usmerňovali činnost' v jednotlivých oblastiach školstva, vedy a kultúry. ${ }^{25}$ Odbor pamiatok a múzeí prináležal pod patronát V. odboru umenie a osveta. Sekčným šéfom pre otázky múzeí, múzejníctva a ochrany pamiatok sa stal Vladimír Wagner ${ }^{26}$, kunsthistorik a pamiatkar. V danej oblasti mal bohaté skúsenosti, pretože $\mathrm{v}$ medzivojnovom období pôsobil ako jeden z pracovníkov Štátneho referátu na ochranu pamiatok. ${ }^{27}$

Následky marcových udalostí roku 1939 sa, pochopitel'ne, premietli aj do fungovania organizácie, ktorá na dobrovol'nej báze zastrešovala múzejníkov v spoločnej republike. Sväz československých museí sa rozpadol. Spájania pracovníkov v múzeách sa chopili zamestnanci Slovenského národného múzea v Turčianskom Svätom Martine, jedného z najväčších múzejných pracovísk na Slovensku. Kým bratislavské múzeá

\footnotetext{
${ }^{15}$ JŠK, Otázky nateraz bez odpovede, Kultúra, 1941, roč. 13, č. 7-8, s. 325-327.

${ }^{16}$ Konferencia kultúrnych pracovníkov sa uskutočnila v Tatranskej Lomnici na konci augusta 1940. Záverom z diskusie, ktorej sa zúčastnili aj niektorí poprední slovenskí umelci a predstavitelia kultúrneho života, medzi inými aj: Valentín Beniak, Ján Smrek, Andrej Žarnov, Milo Urban, Vladimír Rolko alebo Henrich Bartek, bolo presadzovanie slovenského národného socializmu v širokej sfére kultúrneho života. O tom bližšie: I. KAMENEC, Zmietanie sa medzi politikou, s. 135-136.

${ }^{17}$ O situácii vo výtvarnom umení pozri bližšie: Katarína BAJCUROVÁ, Umenie - štát - umelci, in: Katarína BAJCUROVÁ - Petra HANÁKOVÁ Bohunka KOKLESOVÁ, Sen x skutočnost'. Umenie \& propaganda 1939-1945, Bratislava 2017, s. 22 an.

${ }^{18}$ Janko ALEXY, Čo s našim moderným umením?, Kultúra. Revue slovenskej katolíckej inteligencie, 1940, roč. 12, č. 1-2, s. 40-43.

${ }^{19}$ Andrej MRÁZ, Chápanie umenia, Elán, 1942, roč. 13, č. 9. s. 1-2.

${ }^{20}$ I. KAMENEC, Zmietanie sa medzi politikou, s. 138.

${ }^{21}$ Pozri: I. KAMENEC, Zmietanie sa medzi politikou, s. 133 an.

${ }^{22}$ Slovenský zákonník, 1939, s. 30-31.

${ }^{23}$ M. PALÁRIK, Sväz slovenských múzeí, s. 32 an.

${ }^{24}$ BEZ AUTORA, Z činnosti Okresnej osvetovej komisie v Levoči, Slovák, 1943, roč. 25, č. 11, s. 6.

${ }^{25}$ Ministerstvo vnútra Slovenskej republiky, Slovenský národný archív v Bratislave (d’alej SNA v BA), Inventár k fondu Ministerstvo školstva a národnej osvety $1938-1945$, s. $2-3$.

${ }^{26}$ Viac o tejto osobnosti pozri: Ingrid CIULISOVÁ, Vladimír Wagner, prvý slovenský pamiatkar, Pamiatky a múzeá. Revue pre kultúrne dedičstvo, 1995, roč. 44, č. 1, s. 68-70.

${ }^{27}$ Archív Slovenského národného múzea v Bratislave (d’alej ASNM v BA), fond (d’alej f.) Zväz slovenských múzeí (d’alej ZSM), 1939-1959, kr. 1, Zápisničná kniha Zväzu slovenských múzeí, s. 9.
} 
(Slovenské vlastivedné múzeum, Zemedelské múzeum s Lesnícko-loveckým múzeom ako jeho autonómnou zložkou) ${ }^{28}$ preživali krízu, ktorá vyvrcholila ich zlúčením do jedného ústavu s názvom Slovenské múzeum v Bratislave ${ }^{29}$, martinské múzeum malo $\mathrm{v}$ tom čase vytvorené všetky predpoklady na to, aby tu pôsobiaci múzejníci dokázali nielen odborne, ale aj personálne zvládnut' náročnú agendu riadenia oblasti múzejníctva. Na jeho pôde totiž pôsobili významné osobnosti, akými boli napríklad Ján Geryk ${ }^{30}$, Mária Jeršová ${ }^{31}$, ale aj rozporuplná osobnost' - Pavol Florek ${ }^{32}$, ktorý sa postavil na čelo organizácie ako jej výkonný predseda. K nim sa pridali aj d'alší pracovníci, ako napríklad Miloš Jurkovič̌33, Alžbeta Güntherová-Mayerováa ${ }^{4}$ alebo L'udmila Kraskovskáa ${ }^{35}$, ktorí pôsobili v Bratislave. Ich spoločnou víziou bolo vyriešit' aspoň niektoré z fundamentálnych problémov slovenského múzejníctva a tak zabezpečit' jeho kvalitatívne pozdvihnutie. Kým v prípade návrhov riešenia pálčivých problémov slovenského múzejníctva sa im v niektorých prípadoch podarilo nájst' východiská, celá agenda často zlyhávala v praktickom uplatňovaní rozhodnutí predsedníctva novovzniknutého Zväzu slovenských múzeí. V tomto smere zväzovým pracovníkom nepomáhala ani skutočnost', že organizácia nebola inštanciou ministerstva školstva a tak, podobne ako tomu bolo v medzivojnovom období, väčšina rozhodnutí Zväzu zostala len v deklaratívnej podobe. ${ }^{36}$
Prejavom antisemitského postoja politických predstavitel'ov štátu bolo zatvorenie prešovského Židovského múzea, ktoré vzniklo v roku 1928. ${ }^{37}$ Prístup vedúcich členov Zväzu slovenských múzeí k otázke osudu tohto múzea a jeho zbierok poukazuje na možnosti a limity, ktoré ponúkal občanom vtedajší režim. Napriek skutočnosti, že ústav, na čele s Eugenom Bárkányim ${ }^{38}$, mal ambíciu stat' sa členom vtedy ešte len zakladajúceho sa Zväzu slovenských múzeí, organizácia jeho zatvorenie len vzala na vedomie. ${ }^{39}$ Proklamácie členov Zväzu odrážajúce nesúhlas s takýmto postupom úradov sa nekonali. Na druhej strane však Zväz vyvinul aktivitu smerom $\mathrm{k}$ MŠANO, aby prostredníctvom svojich zamestnancov zabezpečilo zbierky múzea pred rozkradnutím alebo zničením. Ministerstvo žiadosti vyhovelo s odôvodnením, že zbierky ,...sú dôležitým dokumentom histórie expanzívnosti (podčiarkol - M. P.) Židov na Slovensku už v minulosti... “. ${ }^{40}$

\section{Múzeá v slovenskom štáte - predstavy a realita}

Predstavitelia politickej moci, spolu s pracovníkmi najmä v menších múzeách ${ }^{41}$, ustrnuli vo svojich predstavách o múzeu ako inštitúcii niekde $\mathrm{v}$ druhej polovici 19. storočia, chápali ich v duchu idey zhromaždísk dokumentov minulosti národa. ${ }^{42}$ Dokazuje to aj vyjadrenie Jozefa Tisa pri

${ }^{28} \mathrm{~K}$ tomu pozri: Elena MACHAJDÍKOVÁ, Slovenské národné múzeum a jeho predchodcovia v Bratislave počas druhej svetovej vojny alebo Inter arma silent musaea, in: Gabriela PODUŠELOVÁ - Viera MAJCHROVIČOVÁ (eds.), Múzeá vo vojne. Druhá svetová vojna a jej dôsledky na činnost’ múzeí a ich zbierky, Bratislava 2015, s. 15-29. Mária HALMOVÁ, Muzeálna slovenská spoločnost’a Slovenské národné múzeum v rokoch 1939-1945, in: Gabriela PODUŠELOVÁ - Viera MAJCHROVIČOVÁ (eds.), Múzeá vo vojne. Druhá svetová vojna a jej dôsledky na činnost' múzeí a ich zbierky, Bratislava 2015, s. 5-14.

${ }^{29}$ Zlúčenie pracovísk do jedného celku bolo skôr politickým ako praktickým rozhodnutím. Je síce pravda, že celé medzivojnové obdobie bolo Slovenské vlastivedné múzeum v Bratislave bez stálych priestorov, ale ani po spojení týchto ústavov sa tieto problémy nevyriešili. Skutočný dôvod je treba vidiet' v tom, že Zemedelské múzeum bolo baštou agrárnej strany, po zastavení činnosti viacerých politických strán v závere roka 1938 preto ústav, ktorý bol oporou tejto strany na Slovensku už nemal opodstatnenie. Slovenské vlastivedné múzeum v Bratislave zase poskytovalo priestor najmä českej vzdelanej elite pôsobiacej na miestnej univerzite. Potom ako sa režim obrátil proti Čechom na Slovensku a viacerí ho museli opustit', ani bratislavské vlastivedné múzeum už nemalo význam umelo udržiavat' pri živote.

${ }^{30} \mathrm{~K}$ osobnosti Jána Geryka pozri napríklad: Štefan BARANOVIČ, Ján Geryk (1892-1978), in: Zborník Slovenského národného múzea v Martine, 1992, roč. 86, Etnografia - 33, s. 11-21.

${ }^{31}$ K osobnosti Márie Jeršovej pozri napríklad: Štefan BARANOVIČ, Mária Jeršová-Opočenská 1899-1978. Život a dielo. Edícia medailóny, zv. VI., Bratislava 1989.

${ }^{32}$ Pavol Florek bol historik, múzejník, poslanec za Hlinkovu slovenskú l’udovú stranu v Sneme Slovenskej republiky a predseda jej miestnej pobočky v Turčianskom Svätom Martine. Jeho odborné historické a muzeologické znalosti nemožno spochybňovat'. Reputáciu si však pokazil najmä politickou agilitou. Bol oddaným prívržencom štátnej ideológie, čo dával otvorene najavo aj v múzeu. Po vojne emigroval s rodinou do Talianska. Po návrate bol súdený v rámci retribučného súdnictva. Súd ho nepotrestal odňatím slobody, ale musel prejst’ tzv. prevýchovou, čo znamenalo prácu vo výrobe a mimoriadne vojenské cvičenie. Bližšie o tom pozri: Augustín MAŤOVČÍK, Príspevok k životopisu Pavla Florka, in: Augustín MAŤOVČÍ́K (ed.), Biografické štúdie. 23/1996, Martin 1996, s. 171-177; M. HALMOVÁ, Muzeálna slovenská spoločnost', s. 5-14; Marcel LALKOVIČ, Pavol Florek - prvý predseda Zväzu slovenských múzeí, in: Zborník Muzeálnej slovenskej spoločnosti, Martin 1995, s. 78-85; Eva KRÁLIKOVÁ, Pavol Florek. Spomienka k 100. výročiu narodenia (25. 3. 1895-11. 5. 1963), in: Zborník Slovenského národného múzea, 1995, roč. 89, Etnografia - 36, s. 153-155.

${ }^{33} \mathrm{~K}$ osobe Miloša Jurkoviča pozri napríklad: Jozef VONTORČÍK, Výnimočná múzejnícka osobnost' Ing. Miloš Jurkovič, Múzeum, 2000, roč. 46, č. 4, s. 47-48; Ján PODOLÁK, Ing. Miloš Jurkovič (1900-1987), in: Agrikultúra, 1989, roč. 22, s. 7-10.

${ }^{34} \mathrm{~K}$ osobnosti Alžbety Güntherovej-Mayerovej pozri napríklad: Barbora PEKARIKOVÁ, K storočnici Alžbety Güntherovej-Mayerovej (19051973), in: Zborník Slovenského národného múzea, 2005, roč. 99, Etnografia - 46, s. 109-115. O práci Güntherovej-Mayerovej pre štát v akcii dražieb zhabaného židovského majetku pozri: Miroslav PALÁRIK, Osudy pamiatok pochádzajúcich zo židovského majetku za druhej svetovej vojny, in: Historický časopis, 2011, roč. 59, č. 3, s. 515-534.

${ }^{35}$ Katarína TOMČÍKOVÁ, L'udmila Kraskovská. Edícia medailóny, Bratislava 1999.

${ }^{36}$ O problematike činnosti Zväzu slovenských múzeí v rokoch 1939-1945 pozri bližšie: Miroslav PALÁRIK, Múzejníctvo v Slovenskom štáte, in: Egon WIEDERMANN (ed.), Studia Historica Nitriensia 14, Nitra 2008, s. 295-311.

${ }^{37}$ Eugen SABÓL, Bývalé Židovské múzeum v Prešove, Múzeum, 1955, ročník 2, č. 4, s. 51-53.

${ }^{38}$ Jana ŠVANTNEROVÁ, Udalosti z dejín Židovského múzea v Prešove a zo života jeho hlavných aktérov v kaleidoskope osmičkových výročí, in: Daniel HUPKO - Luděk BENEŠ (eds.), Dokumentácia „osmičkových“ výročí v slovenských a českých múzeách. Rok 1918 a tie ostatné, Banská Bystrica 2018, s. 186-217.

${ }^{39}$ ASNM v BA, fond ZSM, 1939-1959, kr. 2/1. List Muzeálnej slovenskej spoločnosti č. 1854/39 adresovaný správam 24 múzeí zo dňa 6. 12.1939. V zozname bolo spísaných 25 múzeí, vyčiarknuté bolo Židovské múzeum v Prešove.

${ }^{40}$ ASNM v BA, fond ZSM, 1939-1959, kr. 2/2, list Prezídia ministerstva školstva a národnej osvety adresovaný Predsedníctvu vlády v Bratislave pod č. 16.001/42 - prez. dňa 17. 4. 1942.

${ }^{41}$ Dokazovali to revízne správy z jednotlivých múzeí, ktoré vypracovávali odborníci poverení touto činnost’ou Zväzom slovenských múzeí. Pozri: Miroslav PALÁRIK, Výročné zjazdy a kurzy Zväzu slovenských múzeí a ich vplyv na d'alší rozvoj slovenského múzejníctva v rokoch 1940-1945, in: Egon WIEDERMANN (ed.), Studia Historica Nitriensia 15, Nitra 2011, s. 335-354.

${ }^{42} \mathrm{~K}$ tomu pozri: Anna GREGOROVÁ, Múzeá a múzejníctvo, Martin 1984, s. 56-57. 
príležitosti vyhlásenia programu vlády Slovenskej krajiny vo februári 1939, kde zdôraznil: „...Doterajšie historické a národné hodnoty hodláme zachovat' zvýšenou ochranou svojich národných a umeleckých pamiatok a ich sústredením $v$ Slovenskom národnom múzeu..." "43 Je príznačné, že si v tejto reči spomenul predseda vládnucej strany na najstaršie slovenské múzeum a ostatné, hoci vekovo podobné, ale zakladané na inom národnom príbehu, sa do vyhlásenia nedostali. Šíreniu tohto obrazu napomáhala skutočnost', že v tom čase neexistovala žiadna legislatívna norma, ktorá by definovala múzeum a náplň jeho činnosti. Napriek tejto skutočnosti sa múzeá v slovenskom štáte mali starat' o posilňovanie nacionálneho cítenia, mali sa stat' jedným z prostriedkov vlasteneckej výchovy ${ }^{44}$, čím by sa zaradili medzi šíritel'ov ideológie štátostrany a rôznych mýtov o ceste k samostatnosti Slovákov. ${ }^{45}$ Zdôrazňovanie niektorých tém však vyvolávalo rozporuplné reakcie. Napríklad politikmi a historikmi akcentovaná vel'komoravská tradícia, v ktorej bola Vel'ká Morava predstavovaná ako prvý štát Slovákov ${ }^{46}$, narážala, v prípade narácie o antagonizme Vel'komoravanov proti germánskym Frankom, na nesúhlas zo strany Nemecka. Téma preto nebola príliš vhodná na prezentovanie verejnosti, respektíve sa $\mathrm{k}$ nej muselo pristupovat' vel'mi citlivo. $\mathrm{V}$ opačnom prípade mohlo dôjst' ku konfliktom tak, ako tomu bolo v napríklad $\mathrm{v}$ divadelníctve, kde niektoré hry s vel'komoravskou tematikou museli byt' z javísk stiahnuté. ${ }^{47}$

Vzhl'adom na vzdelanostné zloženie obyvatel'ov Slovenska - prevažná väčšina $\mathrm{z}$ nich dosiahla len základné vzdelanie ${ }^{48}$, možno predpokladat', že pamät'ové inštitúcie neboli medzi vyhl'adávanými formami trávenia vol'ného času väčšinového obyvatel'stva Slovenska. Najčastejšími návštevníkmi bola školopovinná mládež ${ }^{49}$, čomu mali byt' postupne prispôsobené aj expozície v múzeách, aby forma odovzdania posolstva, $\mathrm{v}$ tomto prípade štátnoideologického, bola čo najúčinnejšia. Pre totalitné režimy je typické, že na šírenie svojej ideológie využívajú všetky druhy kultúrnych a osvetových zariadení ako prostriedky l'udovej výchovy. ${ }^{50}$ Už koncom 30 . rokov vykazovalo celkové ladenie expozícií a vnímanie zbierkového predmetu v sovietskom a nemeckom múzejníctve spoločné črty. Podl’a týchto koncepcií mali mat' múzeá a expozície jednoznačne pedagogický a výchovný charakter, so snahou o ovplyvňovanie myslenia návštevníka. Múzeá vo vyššie uvedených krajinách sa stali ústavmi, ktoré prezentovali skôr politický, sociálny a hospodársky vývoj. Expozície mali pôsobit' ako učebnice, delit' sa na jednotlivé kapitoly a podkapitoly, pričom exponáty, doplnené rôznym pomocným materiálom, boli vnímané len ako sociálny alebo historický činitel'. Expozície sa mali vzt’ahovat' najmä na prítomnost' a na národnostné a občianske zaradenie návštevníka. ${ }^{51}$ Dôležitým aspektom reflektovaným vo výstavníctve bolo ukázat' aktuálne výdobytky a pokrok, ktorý národ zaznamenal vd’aka politickým predstavitel'om vládnuceho režimu. Tento spôsob exponovania bol teda $\mathrm{v}$ zásade odlišný od snahy o vyvolanie emócii u návštevníka, kde expozícia vytvárala historickú atmosféru, ukazovala minulost' pre ňu samu a nekládla až taký dôraz na výchovnú a pedagogickú stránku, hoci ju vyvolaním zážitku naplńala. Vyššie uvedený trend v múzejnom výstavníctve sa aplikoval najmä v Nemecku a práve Nemecko bolo štátom, z ktorého slovenskí múzejníci preberali inšpirácie ${ }^{52}$ a snažili sa ich zavádzat' do praxe. Významná súdobá slovenská múzejníčka a kunsthistorička, Alžbeta Güntherová-Mayerová, navrhovala v článku „,O súčasnom muzejníctve“, ktorý vyšiel v Časopise Muzeálnej slovenskej spoločnosti, preinštalovat' expozície v slovenských múzeách v zmysle rešpektovania pedagogickosti. Vo svojich úvahách vychádzala $\mathrm{z}$ prác nemeckého profesora Jacob-Friesena, ktorý presadzoval zavádzanie princípov pedagogiky do múzejnej praxe, čím sa umožňovalo využívanie múzeí na propagandistické ciele. Upozornila tiež na skutočnost', že v slovenskom prostredí sa nevyužíva upozorňovanie návštevníka na rozdiely a spoločné črty príslušníkov jednotlivých etník. Podobne sa Güntherová-Mayerová vyjadrovala i v príručke určenej pracovníkom v múzeách. V stati s názvom: „Inštalácia zbierok podl'a moderných zásad muzeologických" sa prikláňala k prvej popísanej možnosti inštalovania zbierok. ${ }^{53} \mathrm{~V}$ tomto duchu mali byt' následne preinštalované expozície v slovenských múzeách. ${ }^{54}$ Je však nutné upozornit', že išlo o vojnové obdobie, ked' múzeá pracovali v provizórnych podmienkach. Množstvo expozícií bolo rozobratých, pretože si to vyžadovali

${ }^{43}$ Miroslav FABRICIUS - Katarína HRADSKÁ (eds.), Jozef Tiso. Prejavy a články (1938-1944), Bratislava 2007, s. 83.

${ }^{44}$ Porovnaj: Vyhláška MŠANO zo dña 30. apríla 1940, číslo 3277/40 - prez. O usporiadaní školských vychádzok a zájazdov, in: Zvesti MŠANO, 1940, roč. 3, č. 5, s. 89; Učebné osnovy pre učitel'ské akadémie. Zásadné stanoviská, in: Zvesti MŠANO, 1940, roč. 3, č. 5, s. 302-361.

${ }^{45} \mathrm{~K}$ mýtu obete pozri napríklad: Vladimír KRIVÝ - Elena MANNOVÁ, Mýtus obete, in: Eduard KREKOVIČ - Elena MANNOVÁ - Eva KREKOVIČOVÁ, Mýty naše slovenské, Bratislava 2005, s. 77-85. Mýty Slovenského štátu popisuje: Ivan KAMENEC, Slovenská republika 1939-1945 a jej mýty, in: E. KREKOVIČ - E. MANNOVÁ - E. KREKOVIČOVÁ, Mýty naše slovenské, s. 181-198.

${ }^{46}$ Slávka OTČENÁŠOVÁ, Cyrilo-metodská tradícia v československých a slovenských učebniciach dejepisu publikovaných po roku 1918, in: Martin HETÉNYI - Peter IVANIČ - Martin HUSÁR - Martina LUKÁČOVÁ (eds.), Tradícia a prítomnost' misijného diela sv. Cyrila a Metoda, Nitra 2013, s. 256-268.

${ }^{47}$ Bližšie pozri: M. PALÁRIK, Divadelníctvo v Nitre, s. 377.

${ }^{48}$ Viera PILINSKÁ, Zmeny v štruktúre obyvatel'stva podl'a veku, rodinného stavu a vzdelania na Slovensku po vzniku Československa, in: Slovenská štatistika a demografia, 2018, roč. 18, č. 4, s. 29 an. Pilinská uvádza, že prvýkrát sa na Slovensku zist'ovalo najvyššie dosiahnuté vzdelanie až počas sčítania l'udu v roku 1950, dovtedy sa úrady zaujímali iba o gramotnost' občanov.

${ }^{49}$ ASNM v BA, fond ZSM, 1939-1959, kr. 2/2, Výročné správy múzeí na Slovensku za rok 1942 zaslané Zväzu slovenských múzeí.

${ }_{50}^{50, . . .5 ̌ ́ f ~ p r o p a g a n d y ~ S ̌ a n ̌ o ~ M a c h ~ v y h l a ́ s i l ~ r e d a k t o r o v i ~ N e u e ~ F r e i e ~ P r e s s e, ~ z ̌ e ~ p r v o u ~ u ́ l o h o u ~ u ́ r a d u ~ s l o v e n s k e j ~ p r o p a g a n d y ~ b u d e ~ o d s t r a ́ n e n i e ~ p r o t i s l o v e n s k y ́ c h ~}$ a židovských redaktorov a spisovatelov. Našim cielom je - vyhlásil Šaňo Mach-aby tlač, literatúra, rádio, divadlo a film pomohli $\mathrm{k}$ vit’azstvu myšlienky novej slovenskej vlády..." BEZ AUTORA, Šaňo Mach o plánoch slovenskej propagandy, Slovenská politika, 1938, roč. 19, č. 250 , s. 3.

${ }^{51}$ Porovnaj: BEZ AUTORA, Přerod v musejnictví, Zprávy památkové péče, 1938, roč. 2, č. 1, s. 4.

${ }^{52}$ Porovnaj: Alžbeta GÜNTHEROVÁ-MAYEROVÁ, O súčasnom muzejníctve, Časopis Muzeálnej slovenskej spoločnosti, 1940, roč. 31, č. 2, s. 4142. O múzejnej pedagogike v tridsiatych rokoch 20. storočia pozri: Friedrich WAIDACHER, Príručka všeobecnej muzeológie, Bratislava 1999, s. 76-77; Thorsten HEESE, ,....ein eigenes Local für Kunst und Alterthum “. Die Institutionalisierung des Sammelns am Beispiel der Osnabrücker Museumsgeschichte [online], Martin Luther University of Halle-Wittenberg, Halle, 2002, [30. 08. 2015]. Dostupné na internete: http://digital. bibliothek.uni-halle.de/ulbhalhssun/content/titleinfo/2589814.

${ }^{53}$ Alžbeta GÜNTHEROVÁ-MAYEROVÁ, Inštalácia zbierok podla moderných zásad muzeologických, in: Ján GERYK a kol., Odborné práce v múzeách: pokyny pre správcov múzeí, Turčiansky Svätý Martin 1942, s. 39-53.

${ }^{54}$ ASNM v BA, f. ZSM, 1939-1959, kr. 1, Zápisničná kniha Zväzu slovenských múzeí, s. 14-15, 54. 
bezpečnostné opatrenia v rámci civilnej protileteckej obrany. ${ }^{55}$ K preinštalovaniu expozícií došlo počas trvania slovenského štátu iba v štyroch slovenských múzeách: v Mestskom múzeu v Banskej Bystrici, Banskej Štiavnici, Kremnici a Kežmarku. ${ }^{56}$ Predstavy Hlinkovej slovenskej l'udovej strany o múzeách ako prostriedkoch vlasteneckej výchovy narážali na každodennú múzejnícku realitu, v ktorej najmä menšie, regionálne múzeá bojovali s nedostatkom personálu, skladových a výstavných priestorov, respektíve s akoukol'vek koncepciou expozičnej činnosti. Vel'ká čast' múzeí na Slovensku ustrnula na úrovni starožitníckych výkladov, kde sa návštevníkovi prezentovalo prakticky všetko, čo sa v ňom aktuálne nachádzalo. Pri takto koncipovaných ,výstavách“ sa len t’ažko mohlo uvažovat' nad hojnejšou návštevnost'ou, i tak ovplyvnenou vojnovým obdobím, alebo aktívnejším šírením filozofie štátostrany.

Pri dnešnej úrovni poznania vývoja v oblasti múzejníctva na Slovensku v období druhej svetovej vojny možno konštatovat', že menšie, regionálne múzeá „nestáli“ pre štátostranu v oblasti šírenia ideológie a propagandy na prvom mieste. Zaujímavejšie boli skôr vel'ké ústavy v Bratislave a Turčianskom Svätom Martine. Vzhl'adom na zameranie ich zbierkotvorného programu poskytovali obe inštitúcie dostatočné množstvo pramenného materiálu na vytváranie expozícií koncepčne zapadajúcich do požiadaviek vládnej moci. Bratislavské múzeá zaznamenávali v porovnaní s menšími múzejnými pracoviskami vyššiu návštevnost', čomu napomáhal fakt, že v meste žilo viac obyvatel'ov s vyšším stupňom vzdelania. Múzeum v centre Turca bolo už od svojho vzniku prezentované ako výkladná skriňa slovenského národa a to mu v očiach verejnosti dodávalo doslova punc posvätného stánku minulosti Slovákov. Slovenské múzeum v Bratislave, po počiatočných turbulenciách, usporiadalo niekol'ko výstav, ktoré možno označit' za štátnoideologické, či už to boli výstavy Deutsche Partei, ale širší priestor dostávali i umelci akcentujúci v dielach národnú tematiku. ${ }^{57} \mathrm{~V}$ Slovenskom národnom múzeu v Turčianskom Svätom Martine sa jeho riaditel', Pavol Florek, snažil prispôsobit' priestory reprezentačným potrebám štátu. Múzeum navštívilo niekol'ko oficiálnych štátnych delegácií, vrátane prezidenta Jozefa Tisa, šéfa Úradu propagandy Alexandra Macha a rôznych nemeckých hostí, ktorí prišli na pozvanie riaditel'a. Florek sa snažil, aby expozície múzea boli doplnené o nemecky písaného sprievodcu a do nemčiny mal byt' preložený aj popisný materiál. Nakoniec k týmto zmenám nedošlo. Na druhej strane je potrebné spomenút' aj fakt, že v múzeu zostali pracovat' aj zamestnanci, ktorí z národnostného a politického hl'adiska odporovali predstavám vládneho režimu. ${ }^{58}$ Dôvodom na tento postoj mohlo byt' to, že režim nedisponoval dostatočným množstvom oddaných vzdelancov, ktorí by nahradili pre štát „,nespol’ahlivých“ pracovníkov. Pokial' to bolo možné a títo zamestnanci výrazne neprispievali k poburovaniu proti vládnej moci, nechali ich na svojich miestach. V prípade nutnosti mali politickí predstavitelia stále $\mathrm{k}$ dispozícii zastrašovacie metódy (internovanie $\mathrm{v}$ tábore pre politických väzňov v Ilave), ktoré by neváhali využit'. ${ }^{59}$

Vplyv politickej moci na múzeá sa výraznejšie prejavil $\mathrm{v}$ hlavnom meste. Bratislavské múzeá (Slovenské múzeum a Mestské múzeum ${ }^{60}$ ), vzhl'adom na bezprostrednú blízkost' predstavitel'ov štátu a centrálnych inštitúcii, usporiadali v tomto období niekol'ko výstav, ktoré sa niesli v štátnoideologickom duchu. Priestor v nich dostávali i umelci, ktorých námety boli národné, zrozumitel'né pre čo najširšie publikum. Oficiálna štátna ideológia bola šírená aj prostredníctvom dvoch nových inštitúcií $\mathrm{v}$ hlavnom meste krajiny - Vojenského múzea (verejnosti bolo sprístupnené v roku 1940) a Slovenského hygienického múzea (otvorené v roku 1941). Vojenské múzeum vystavovalo najmä ukoristený vojenský materiál z t’aženia proti Sovietskemu zväzu. ${ }^{61}$ Múzeum hygieny bolo zase filiálkou drážd'anského hygienického múzea. Na jeho vzniku aktívne participovala Slovensko-nemecká spoločnost', na čele ktorej stál radikálny pronacisticky orientovaný predstavitel' HSL'S a predseda vlády Vojtech Tuka. Vzhl'adom na zameranie „materského múzea“ na dokumentáciu eugeniky možno predpokladat', že aj jeho bratislavská pobočka bola podobne orientovaná a šírila rasovú ideológiu na Slovensku. ${ }^{62}$ Doterajší výskum neumožňuje exaktné konštatovanie, ako ovplyvňovala súdobá vládna moc činnost' múzeí v ostatných častiach republiky. Zatial' máme zmapované expozičné aktivity múzeí a iných kultúrnych inštitúcií na území mesta Bratislava ${ }^{63}$, ostatné lokality zatial' na výskum čakajú. Jediný záver, ktorý možno nateraz

\footnotetext{
${ }^{55}$ ASNM v BA, f. ZSM, 1939-1959, kr. 1, Zápisničná kniha Zväzu slovenských múzeí, s. 14-15, 54.

${ }^{56}$ ASNM v BA, f. ZSM, 1939-1959, kr. 2/1, Revízne správy o múzeách.

${ }^{57}$ E. Machajdíková (E. MACHAJDÍKOVÁ, Slovenské národné múzeum a jeho predchodcovia) uvádza iba výstavy Deutsche Partei: Výstava nemeckých výtvarníkov zo Slovenska a Die Volksgruppe plant und baut. Medzi výstavy, ktoré námetmi napíňali predstavy štátnej moci o ideálnom umení, však možno zaradit' i výstavy umelcov ako napríklad Jozefa Satina, Milovana Krakera, Františka Viktora Podolaya a iných (podrobný zoznam pozri: Z. FALATHOVÁ, Múzejníctvo a výstavníctvo). Štát sa tiež pravidelne snažil prinášat' umenie v krajinách patriacich do sféry vplyvu nacistického Nemecka, takýmito podujatiami boli: Výstava chorvátskeho výtvarného umenia a Výstava súčasného rumunského umenia. Z hl’adiska tematickej preferencie predstavitel'ov HSL'S môžeme považovat' za štátnoideologickú i výstavu s názvom: Celoštátna výstava poštových známok. Po vzniku Slovenskej republiky boli navrhnuté nové poštové ceniny, na ktorých boli prezentované národné témy - objavili sa na nich napríklad idealizované podoby vel'komoravských kniežat, ochranné nemecké lietadlá nad Slovenskom, či séria malieb s l'udovou tematikou od Martina Benku. Bližšie o tom pozri napríklad: Miroslav PALÁRIK - Zuzana HASARová, Medzníky slovenských a československých dejín na známkach z filatelistickej zbierky Slovenského národného múzea, in: Miroslav PALÁRIK - Peter KERESTÉŠ - Milan BELEJ (eds.), Míl’niky 20. storočia v regióne Nitrianskeho kraja, Nitra 2018, s. 111-139.

${ }^{58}$ M. HALMOVÁ, Muzeálna slovenská spoločnost', s. 5-14.

${ }^{59} \mathrm{~K}$ tomu pozri napríklad: Marína ZAVACKÁ, L'udácka prevýchova. Mária Janšáková v Ilave roku 1939 a jej Cela č. 20 , Bratislava 2018.

${ }^{60} \mathrm{O}$ výstavných aktivitách Mestského múzea v Bratislave pozri bližšie: Elena KURINCOVÁ, Múzeum mesta Bratislavy počas druhej svetovej vojny, in: Gabriela PODUŠELOVÁ - Viera MAJCHROVIČOVÁ (eds.), Múzeá vo vojne. Druhá svetová vojna a jej dôsledky na činnost’ múzeí a ich zbierky, Bratislava 2015, s. 54-63.

${ }^{61} \mathrm{O}$ tom bližšie: Peter CHORVÁTH, Vojenské múzeum v Bratislave 1939-1945 (plány versus realita), Vojenská história. Časopis pre vojenskú históriu, múzejníctvo a archívnictvo, 2012, roč. 16, č. 3, s. 6-16.

${ }^{62} \mathrm{~K}$ aktivitám Slovenského hygienického múzea v Bratislave pozri napríklad: Miroslav PALÁRIK, Príspevok $k$ dejinám múzejných činností na Slovensku. (Hygienická výstava - „Zázrak života“), in: Egon WIEDERMANN (ed.), Studia Historica Nitriensia 13, Nitra 2006, s. 251-260.

${ }^{63}$ Zuzana FALATHOVÁ, Múzejníctvo a výstavníctvo v Bratislave v období prvej Slovenskej republiky (1939-1945), Muzeológia a kultúrne dedičstvo, 2017, roč. 5, č. 2, s. 61-76.
} 
vyvodit', je, že prezentovanie štátnej ideológie v priestoroch múzeí do vel'kej miery záležalo od jej pracovníkov a ich politického presvedčenia. Nové poznatky by mohol priniest' podrobný výskum v súdobých múzejných ústavoch, zameraný na analýzu zachovanej múzejnej dokumentácie (kniha návštev, kniha prírastkov, katalóg, dokumentácia k expozíciám, lektorské slovo), respektíve dobovej tlače. Múzejnícku historiografiu by obohatil aj výskum v pracoviskách, ktoré pripadli po Viedenskej arbitráži do Mad'arska (boli to Štátne východoslovenské múzeum v Košiciach, Mestské múzeum v Komárne, Mestské múzeum v Leviciach, Gemerské múzeum v Rimavskej Sobote a Mestské múzeum v Rožňave). O týchto múzeách dnes vieme len vel'mi málo informácií.

Nacistická propaganda sa na Slovensku presadzovala aj prostredníctvom výstav, tie sa však inštalovali mimo priestorov múzeí. Tieto krátkodobé akcie, zamerané na hlásanie prvkov a výdobytkov nacionálneho socializmu, mali na starosti Úrad propagandy, Slovensko-nemecká spoločnost', Nemecká strana na Slovensku alebo organizácie sprostredkujúce kultúrnu spoluprácu medzi Nemeckou ríšou a slovenským štátom. Snahy o ovplyvnenie slovenskej kultúry „novými impulzmi“ z Nemeckej ríše dokumentuje aj článok s názvom „K návšteve ríšskeho ministra Rusta“, ktorý bol pri tejto príležitosti uverejnený v novinách Slovák v auguste 1941: ,Slovensko po vzniku svojho štátu stálo duchovne pevne a tento stav sa deň čo den̆ zlepšuje. Línia strany, ktorá mala vždy na zreteli i duchovné pulzovanie národa, spôsobila, že dnes stačí nám len kráčat'za touto osvedčenou líniou. Okrem tejto vlastnej línie, usilujúcej sa o vlastnú duchovnú individualitu, pomohla nám v tom, že u nás nenastal duchovný chaos, i skutočnost', že sme sa usilovali vziat'si za vzor v duchovnom živote všetky tie štáty, ktoré priniesli nový život a ktoré širili nové myšlienky a nové idee, ktoré preformovali starú Európu. Tu je a bude nám vzorom predovšetkým nové Nemecko, v ktorom nové duchovné prúdy umožňujú nový, nebývalý vzrast kultúry. My, Slováci, budeme sa musiet' snažit' čo najviac t'ažit'z nového kultúrneho pulzovania v Nemecku a želáme si, aby návšteva ministra Rusta stala sa d’alším posilnením vzájomných kultúrnych vzt'ahov. “64 „Kultúrne" výstavné akcie organizované vyššie spomenutými inštitúciami boli často usporadúvané pod záštitou predstavitel'ov štátu. ${ }^{65}$ Ich primárnou úlohou bolo priblížit’ nemecký nacionálny socializmus slovenskej verejnosti, upozornit' na jeho pozitíva, a tak vtláčat’ reakčnú ideológiu do mysle občanov. Výstavy boli vždy precízne pripravené, takže vedeli l'udí zaujat'. Aby sa dosiahla čo najvyššia návštevnost', získavali návštevníci zl’avy na cestovnom. Výstavy mali putovný charakter a prešli viacerými slovenskými mestami. Vstupné sa v zásade neplatilo alebo bolo len symbolické. Napríklad redaktor Slováka opísal výstavu nemeckej knihy v Bratislave takto: „,...výstava nám vo výbere predvádza a ukazuje hlavne knihy a publikácie, ktoré vydalo súčasné Nemecko. Na čele ústrednej výstavnej siene sú pod Hitlerovou podobizňou diela tvorcov dnešného Nemecka, od Hitlerovho základného diela ,Mein Kampf'až po diela jeho spolupracovnikov, ministrov a popredných pracovníkov národne-sociálneho hnutia. "66 V podobnom duchu sa niesla aj Protibol’ševistická výstava, na margo ktorej redaktor Slováka poznamenal: ,....na výstave v slovenskom oddelení sú listy, ktoré písali zblúdili katolícki slovenskí robotníci, ktorí odišli do sovietskeho raja. Sú najlepším dôkazom, ako zotročili robotnikov v Rusku, ktoré od roku 1917 stalo sa domovom otroctva. Je povinnostou každého statočného Slováka, aby poznal dôkladne nebezpečenstvo bol'ševických hesiel. Každý Slovák dnes bojuje proti bol'ševizmu najlepšie tým, že sa vzdeláva a poučuje $z$ odbornej literatúry, najmä z tých štátov, ktoré tak úspešne bojujú proti rudému teroru." ${ }^{\text {"67 }}$ Medzi akcie tohto druhu na Slovensku patrili už spomenuté: „Protibol'ševistická výstava“ v Bratislave, ${ }^{68}$, "Výstava nemeckej knihy“" v Bratislave a v Prešove, ${ }^{69}$ ale aj výstava „Človek - zázrak života“ v Bratislave, v Prešove, v Banskej Bystrici a v Nitre ${ }^{70}$ alebo „Hradské Adolfa Hitlera" v Bratislave ${ }^{71}$.

\section{Úroveň dokumentácie súčasnosti v dvoch najväčších slovenských múzeách}

Múzeá ako pamät'ové inštitúcie mohli svojou dokumentačnou a expozičnou činnost'ou prispiet' $\mathrm{k}$ utvrdzovaniu $\mathrm{v}$ tom čase konštruovaného národného príbehu, založenom na odvekej snahe Slovákov o vytvorenie si vlastného štátu, v podobe, ako ho podal Jozef Tiso, predseda Hlinkovej slovenskej l'udovej strany, 14. marca 1939 v rozhlasovom prejave. V ňom tvrdil,

${ }^{64}$ BEZ AUTORA, K návšteve rišskeho ministra Rusta, Slovák, 1941, roč. 23, č. 184, s. 3. Užšia kooperácia slovenského štátu a Nemeckej ríše v oblasti kultúry, proklamovaná aj niektorými predstavitel'mi štátu, bola podporená uzavretím „Dohody medzi Slovenskou republikou a Nemeckou rišou o spolupráci na kultúrnom poli“, ktorá vstúpila do platnosti 18. 1. 1943. Pozri: Slovenský zákonník 1943, Vyhláška ministra zahraničných vecí zo dňa 5. 2. 1943, s. 189. K problematike ohlasu a praktického napíňania „kultúrnej dohody“ medzi tret’ou ríšou a prvou Slovenskou republikou pozri bližšie: S. DRAGÚŇ, Nemecko-slovenská dohoda z roku 1942, s. 559-576. O slovensko-nemeckých kultúrnych vzt’ahoch v sledovanom období pozri: Ivan KAMENEC, V pozícii duchovného satelita. Miesto kultúry v slovensko-nemeckých vztahoch v čase druhej svetovej vojny, História. Revue o dejinách spoločnosti, 2009, roč. 9, č. 5-6, s. 76-80.

${ }^{65}$ Napríklad Alexandra Macha - velitel’a Hlinkovej gardy, šéfa Úradu propagandy a ministra vnútra, alebo Vojtecha Tuku, ktorý bol zakladatel’om Slovensko-nemeckej spoločnosti v Bratislave, predseda vlády a minister zahraničných vecí. O angažovanosti týchto politikov v oblasti kultúry pozri bližšie: Ivan KAMENEC, Slovenský stát. Praha 1992, s. 99-106.

${ }^{66}$ BEZ AUTORA, Skvelý obraz nemeckej dokonalosti, Slovák, 1940, roč. 22, č. 18, s. 7. Výstava bola usporiadaná pod záštitou Dr. Vojtecha Tuku v pavilóne Spolku slovenských umelcov v Bratislave.

${ }^{67}$ BEZ AUTORA, Protibol'ševická výstava doplnená slovenským materiálom, Slovák, 1939, roč. 21, č. 92, s. 3. Výstava bola usporiadaná pod záštitou Úradu propagandy.

${ }^{68}$ BEZ AUTORA, Protibol'ševická výstava, s. 3. Jej putovanie zabezpečilo inštalovanie v niekol’kých vozňoch, ktoré prechádzali železničnými stanicami na Slovensku. Išlo o typickú propagandistickú akciu, ktorá reagovala na vývoj na fronte a mala navnadit’ Slovákov do boja proti Sovietskemu zväzu.

${ }^{69}$ BEZ AUTORA, Skvelý obraz nemeckej dokonalosti, s. 7.

${ }^{70}$ BEZ AUTORA, Hygienická výstava bude v Nitre, Nitrianska stráž, 1943, roč. 22, č. 20, s. 3; BEZ AUTORA, Otvorenie hygienickej výstavy v Nitre, Nitrianska stráž, 1943, roč. 22, č. 21, s. 3; BEZ AUTORA, Prechádzka výstavou hygieny, Nitrianska stráž, 1943, roč. 22, č. 22, s.1. Výstavu pripravila Slovensko-nemecká spoločnost' (ako vlastník zbierok Hygienického múzea), Hygienické múzeum v Bratislave a zdravotný odbor ministerstva vnútra, a to pod záštitou Alexandra Macha. O tejto akcii pozri bližšie: Miroslav PALÁRIK, Aktivity Slovensko-nemeckej spoločnosti v oblasti múzejníctva v rokoch 1941-1945. (Slovenské hygienické múzeum v Bratislave), in: Marcela OBRECHTOVÁ - Václav ZEMAN (eds.), Fenomén muzeum v 19. a první polovině 20. století: XVIII. ústecké kolokvium. Ústí nad Labem 22.-23. dubna 2010, Ústí nad Labem 2011, s. 83-100.

${ }^{71}$ SNA v BA, fond Policajné riaditel'stvo v Bratislave, kr. 67. 
že: ,...Splnili sa túžby našej národnej ambicie, ktorá poháňala životnú silu národa $k$ tomu, aby riadenie svojich vecí mal národ celkom, úplne a bezvýhradne vo svojich rukách. Náš samostatný Slovenský štát zrodil sa teraz dôsledne v rozvinovanej politickej vôle národa slovenského vládnut' sám nad sebou na celej čiare, neodvisle od kohokol'vek. Vznikol teda z hlbokých kladných síl, ktoré budili oduševnenie, tvorili hodnoty, budovali prácou a sledovali priamu čiaru historického vývinu národa slovenského..."72 Tento mýtus ohl'adom založenia štátu d'alej šírili oficiálne politické kruhy, hoci vedeli, že skutočnost' bola odlišná. Vznik nového štátu a jeho etablovanie sa stalo pre slovenských múzejníkov ideálnym priestorom na dokumentáciu súčasnosti, rýchlo nasledujúcich politických a spoločenských zmien a zároveň štátom deklarovaného pokroku v porovnaní s predchádzajúcim obdobím. Na to však potrebovali dokonale poznat' múzejnícku problematiku. Prax však ukazovala, že väčšina múzeí na Slovensku mala problém už i so základnými múzejnými činnost'ami, ako boli napríklad premyslená koncepcia zbierkotvornej činnosti, vedecké spracovanie zbierok a ich správne inštalovanie. Pracovníkmi v múzeách boli miestni vzdelanci - učitelia, kňazi a iní dobrovol'níci, ktorí nemali potrebné skúsenosti a aspoň základné múzejnícke zručnosti. Možno preto predpokladat, že dokumentácia súčasnosti im bola vzdialená a pravdepodobne skôr závisela na vnútornom zžití sa toho-ktorého pracovníka múzea s konceptom vzniku slovenského štátu a jeho politiky.

Dokumentácia súčasnosti bola v 20. storočí (a je tomu tak aj dnes) často pertraktovaná ${ }^{73}, \mathrm{v}$ Československu najmä v období po februári $1948^{74}$, pričom sa $\mathrm{k}$ nej vyjadrili poprední predstavitelia muzeológie doma i v zahraničí. Problematickým sa môže javit' ponímanie slova súčasnost'. Čo je súčasnost'ou a čo do nej už nepatrí? V príspevku chápem časové ohraničenie súčasnosti tak, ako ho definoval Zbyněk Z. Stránský, tzn. obdobie, kedy je muzealizovaný jav v spoločnosti reálne prítomný. ${ }^{75}$ Výskum, ktorý som vykonal, bol vykonaný v dvoch najväčších slovenských múzejných ústavoch, kde pôsobili odborníci stretávajúci sa s najnovšími trendami v oblasti múzejníctva. Vo februári roku 1941 dokonca usporiadal Zväz slovenských múzeí v Turčianskom Svätom Martine kurz pre pracovníkov v múzeách, kde sa hovorilo aj o dokumentácii súčasnosti, a nedostatky v tomto smere konštatoval Miloš Jurkovič, pracovník Slovenského múzea v Bratislave, v revíznych správach o kontrole múzeí na strednom Slovensku v roku 1942. ${ }^{76}$ Môžeme sa preto domnievat', že o aktívnej dokumentácii poprední slovenskí múzejníci mali v sledovanom čase dostatočné množstvo informácií. Na základe prístupu pracovníkov dvoch najväčších múzeí na Slovensku v tomto období - Slovenského národného múzea v Turčianskom Svätom Martine a Slovenského múzea v Bratislave, k aktívnej selekcii a dokumentácii, je, podl'a môjho názoru, možné rekonštruovat' stav múzejníctva v republike počas druhej svetovej vojny a zároveň postoj jej zamestnancov k novému štátnemu zriadeniu. Prieskumu boli podrobené zachované prírastkové knihy oboch ústavov.

\section{Slovenské národné múzeum v Turčianskom Svätom Martine}

Na základe zápisov z knihy prírastkov možno konštatovat', že z historiografického hl'adiska bolo toto obdobie dokumentované najmä knižnou produkciou. Nešlo však o aktívny prístup zo strany pracovníkov, pretože múzeu boli zasielané povinné výtlačky niektorých titulov, napríklad: diela Andreja Hlinku ${ }^{77}$, Františka Hrušovského ${ }^{78}$, Vojtecha Tuku ${ }^{79}$, Štefana Polakoviča ${ }^{80}$, Karola Sidora ${ }^{81}$ a iných ${ }^{82}$. Podrobne sa

${ }^{72}$ Celý prejav Jozefa Tisa dostupný na internete: https://www.herder-institut.de/no_cache/digitale-angebote/dokumente-und-materialien/themenmodule/quelle/1841/details/2732.html (24. 2. 2020)

${ }^{73} \mathrm{~K}$ problematike pozri napríklad: Kolektív autorov, Teorie a praxe - dokumentace současnosti. Sborník z odborného semináře, Brno 2006; Marek JUNEK, Problematika soudobé dokumentace v Československu pred rokem 1989, Muzeum. Muzejní a vlastivědná práce, 2012, roč. 50, č. 1, s. 3-9; Marek JUNEK, Soudobá dokumentace v České republice po roce 1989, Věstník Asociace muezí a galerií České republiky, 2013, roč. 13, č. 2, s. 17-18; Jan DOLÁK, Dokumentace současnosti a nejnovějši historie doma i ve světě, Věstník Asociace muezí a galerií Ceské republiky, 2013, roč. 13, č. 2, s. 18; Jan DOLÁK, Dokumentace současnosti a nedávne historie. Domácí a zahraniční př́stupy, Museologica Brunensia, 2014, roč. 3, č. 4, s. 34-35; Michal BABÍK, Radeji na stokoruny s Gottwaldem než uctívat baroko, Věstník Asociace muezí a galerií České republiky, 2013, roč. 13, č. 2, s.19-20; Petr NEKUŽA - Pavla STÖHROVÁ, Dokumentace současnosti v oblasti technického dědictví - vlivu spolupráce muzejní instituce se současným výrobním sektorem na strategii její odborné činnosti, Muzeológia a kultúrne dedičstvo, 2019, roč. 7, č. 1, s. 225-233; Zdenka LETENAYOVÁ - Eva ŠEVČÍKOVÁ (eds.), Múzejná dokumentácia druhej polovice 20. storočia na Slovensku. Problematika komplexnej múzejnej dokumentácie obdobia po roku 1989. Zborník príspevkov z konferencie, Bratislava 2012; alebo tematické číslo časopisu Acta Musei Nationalis Pragae - Historia, 2017, roč. 71, č. 3-4.

${ }^{74} \mathrm{~K}$ problematike pozri napríklad: Kolektív autorov, Problémy soudobé dokumentace. (Materiály z celostátního semináre v Brně, listopad 1966), Praha 1968; Zbyněk Z. STRÁNSKÝ, Metodologické otázky dokumentace současnnosti, Muzeologické sešity, 1974, č. 5, s. 13-27; Zbyněk Z. STRÁNSKÝ, Československé i zahraniční zkušenosti a názory na dokumentaci současnosti. Teze muzeologického semináře, Muzeologické sešity, 1974, č. 5, s. 5-11; Jiří ŠPÉT, Jsme připraveni dokumentovat současnost?, Muzejní a vlastivědná práce, 1975, roč. 13, č. 2, s. 53-59; Jiří ŠPÉT, Dokumentace současnosti a muzea, Muzejní a vlastivědná práce, 1989, roč. 27, č. 2, s. 65-74; Jiřina TELCOVÁ, K dokumentaci současnosti v muzeích uménovědného typu, Muzeologické sešity, 1976, č. 6, s. 21-23 a mnohí iní.

${ }^{75}$ Z. Z. STRÁNSKÝ, Metodologické otázky, s. 18.

${ }^{76}$ Porovnaj: M. PALÁRIK, Zväz slovenských múzei, s. 96 a 173.

${ }^{77}$ Andrej HLINKA, Vplyv družstiev na dobrobyt l'udu a prečo sa zakladajú družstvá, Bratislava 1940.

${ }^{78}$ František HRUŠOVSKÝ, Obrázkové slovenské dejiny, Turčiansky Svätý Martin 1942.

${ }^{79}$ Vojtech TUKA, Slovenský štát, Bratislava 1944.

80 Štefan POLAKOVIČ, Warum eine freie Slowakei?, Bratislava 1944; Štefan POLAKOVIČ, Začiatky slovenskej národnej filozofie, Bratislava 1944; Štefan POLAKOVIČ, Slovenský národný socializmus. (Ideové poznámky), Bratislava 1941. K tejto osobnosti pozri napríklad: Michaela LENČ́ŠOVÁ, Comeback Štefana Polakoviča po vzniku Slovenskej republiky. K Polakovičovmu hl'adaniu zmyslu slovenských dejín 20 . storočia, in: Miroslav PALÁRIK - Peter KERESTÉS - Milan BELEJ (eds.), Míl'niky 20. storočia v regióne Nitrianskeho kraja, Nitra 2018, s. 214-227; Anton HRUBOŇ, Slovenský národný socializmus v koncepciách Štefana Polakoviča a Stanislava Mečiara. (Dva návrhy posalzburského smerovania prvej Slovenskej republiky), in: Anton HRUBOŇ - Zuzana TOKÁROVÁ - Juraj LEPIŠ, Slovensko v rokoch neslobody $1938-1989$ II. Osobnosti známe - neznáme. Zborník z vedeckej konferencie Banská Bystrica 22.-23. mája 2012, Bratislava 2014, s. 20-34.

${ }^{81}$ Karol SIDOR, Slovenská politika na pôde pražského snemu (1918-1938), Bratislava 1944.

${ }^{82}$ Ján Balko, Bryndziarsky priemysel na Slovensku, Turčiansky Svätý Martin 1940; BEZ AUTORA, Útokom k vít’azstvu. Obrázkový prehl'ad z dejinných chvil' Slovákov 1938-1940, vydala HSL'S; Valentín BENIAK - Martin BENKA, Strážcovia a ochrankyne Slovenska, Turčiansky Svätý 
dokumentoval život Milana Rastislava Štefánika, čo súviselo najmä s prenesením jeho pozostalosti z Čiech na Slovensko, pričom v sledovanom období bol obraz o tejto osobnosti pozmenený $\mathrm{v}$ duchu potrieb HSL'S, z popredného predstavitel'a československého zahraničného odboja, spoluzakladatel'a ČSR a priatel'a prezidenta republiky Tomáša G. Masaryka sa stal bojovník za práva Slovákov. ${ }^{83}$ Akvizícia predmetov súvisiacich so vznikom nového štátu, jeho politickou orientáciou a autoritatívnym režimom bola dokumentovaná najmä na základe nových emisií poštových známok a kolkov, prípadne bankoviek. Väčšina z nich bola získaná darom od inštitúcií, ktoré mali na starosti ich vydanie. Zaujímavé je, že akcesia predmetov súvisiacich s aktuálnym dianím na Slovensku sa nezvýšila ani pri výročiach vzniku samostatného štátu, dokonca ani pri oslavách 5. výročia, počas ktorého sa bilancoval život $\mathrm{v}$ slovenskom štáte a upozorňovalo na pokrok zaznamenaný v ,prvej pät'ročnici“. Úplne absentuje dokumentácia protižidovskej propagandy, osudov Židov a Rómov počas slovenského štátu. Múzeum neprijalo takmer žiadne predmety súvisiace $\mathrm{s}$ každodenným, prípadne s rozvíjajúcim sa hospodárskym životom. Naopak, po ukončení druhej svetovej vojny sa takmer okamžite (11. 5. 1945) začali do múzea prijímat' pamiatky na Slovenské národné povstanie. Je to pochopitel'né, vzhl'adom na význam tejto udalosti v národných dejinách. A tu do popredia vstupuje zaujímavý fakt, že sa dokumentoval odboj proti vláde a štátu, ktorého negatívne pôsobenie nebolo podrobne zdokumentované. Jedným z dôvodov tohto stavu mohlo byt' demokratické zmýšl'anie, názorový oportunizmus zamestnancov skúmaného ústavu. Avšak to by v ideálnych podmienkach nemalo byt' dôvodom na nevykonávanie činnosti, pre ktorú je múzeum zriadené.

\begin{tabular}{|l|l|l|}
\hline Rok & $\begin{array}{l}\text { Počet prírastko- } \\
\text { vých čísel }\end{array}$ & $\begin{array}{l}\text { Počet prírastkových čísel zodpo- } \\
\text { vedajúcich dokumentácii súčas- } \\
\text { nosti/počet predmetov }\end{array}$ \\
\hline 1939 & 227 & $12 / 14$ \\
\hline 1940 & 331 & $18 / 208$ \\
\hline 1941 & 297 & $20 / 162$ \\
\hline 1942 & 292 & $19 / 19$ \\
\hline 1943 & 376 & $20 / 20$ \\
\hline 1944 & 352 & $23 / 74$ \\
\hline
\end{tabular}

Tabulka č. 1. Počet prírastkov vo fonde Slovenského národného múzea v Turčianskom Svätom Martine v rokoch 1939-1944 zodpovedajúcich dokumentácii súčasnosti. Zdroj: Archív Slovenského národného múzea - Etnografického múzea v Martine, Prírastková kniha Slovenského národného múzea.

\section{Slovenské múzeum v Bratislave}

Negatívnejšie z hl'adiska akvizície predmetov súčasnosti vyšlo druhé najväčšie múzeum na Slovensku - bratislavské Slovenské múzeum. V rokoch 1940 a 1941 rozšírilo múzeum zbierkový fond iba o 11 predmetov, ktoré možno pokladat' za dokumenty súčasnosti. Táto situácia bola spôsobená najmä tým, že inštitúcia a jej predchodcovia prešli v danom čase značne turbulentným obdobím. Okrem samotného vzniku múzea zlúčením dovtedy troch samostatných pracovísk (Zemedelského múzea s Lesnícko-loveckým múzeom ako jeho autonómnou zložkou a Slovenského vlastivedného múzea), to boli aj spory o budovu s inými štátnymi inštitúciami. V roku 1944 zase budovu priamo zasiahli bomby pri leteckých náletoch na Bratislavu. ${ }^{85} \mathrm{~V}$ dokumentácii sa nachádza len niekol'ko predmetov, ktoré by mohli byt' považované za doklad o aktuálnom politickom vývoji v krajine. Zväčša ide o busty vedúcich predstavitel'ov štátu - Andreja Hlinku (zomrel v 16. augusta 1938, ale jeho kult bol v slovenskom štáte aktívne budovaný) a Jozefa Tisa, rôzne knihy, ktoré sa do zbierok dostali ako povinné výtlačky alebo dary od predstavitel'ov Deutsche Partei na Slovensku. Ministerstvo dopravy a verejných prác obohatilo zbierkový fond o niektoré emisie známok, kolkov a bankoviek. Múzeum získalo niekol'ko desiatok kníh (dovedna 28 kusov) zo zhabaného židovského majetku, ale v prírastkovej knihe nie je zmienka o židovských minciach, ktoré mali byt' tiež prijaté do zbierok múzea. ${ }^{86}$

\begin{tabular}{|l|l|l|}
\hline Rok & $\begin{array}{l}\text { Počet prírast- } \\
\text { kových čísel }\end{array}$ & $\begin{array}{l}\text { Počet prírastkových čísel zodpove- } \\
\text { dajúcich dokumentácii súčasnosti/ } \\
\text { počet predmetov }\end{array}$ \\
\hline 1939 & 159 & $17 / 17$ \\
\hline 1940 & 205 & $6 / 6$ \\
\hline 1941 & 259 & $5 / 5$ \\
\hline 1942 & 244 & $12 / 12$ \\
\hline 1943 & 391 & $25 / 46$ \\
\hline 1944 & 178 & $60 / 74$ \\
\hline
\end{tabular}

Tabul'ka č. 2. Počet prírastkov vo fonde Slovenského múzea v Bratislave (a jeho predchodcov) v rokoch 1939-1944 zodpovedajúcich dokumentácii súčasnosti. Zdroj: Slovenské národné múzeum v Bratislave, Prírastková kniha Slovenského múzea.

Martin 1942; Jozef SIVÁK, Pät' rokov slovenského školstva 1939-1943, Bratislava 1944; Ladislav JÁNSKY, Slovenská duchovná tvorba 19391944, Bratislava 1944; BEZ AUTORA, Armáda v obrane a práci. Pät' rokov budovatel'skej činnosti slovenskej armády, Bratislava 1944.

${ }^{83}$ Peter MACHO, Milan Rastislav Štefánik v hlavách a srdciach. Fenomén národného hrdinu v historickej pamäti, Bratislava 2011; Peter MACHO, Pozostalost' Milana Rastislava Štefánika v kontexte inštitucionálnych a rodinných záujmov v medzivojnovom období a vojnovom období, Muzeológia a kultúrne dedičstvo, 2017, roč. 5, č. 1, s. 57-68; Alena MIKULÁŠOVÁ - Miroslav PALÁRIK, Názvy ulíc a námestí v zajatí politiky. Zoznam slovenských dejatelov schválených na pomenovanie verejných priestranstiev v rokoch 1939-1945, Studia historica Nitriensia, 2016, roč. 20 , č. 1, s. 178-211.

${ }^{84}$ Prírastková kniha bola vedená tak, že pod jedným prírastkovým číslom bolo zapísaných viacero predmetov, preto sa počet prírastkových čísel a počet jednotlivých predmetov odlišoval.

${ }^{85}$ O situácii v Slovenskom múzeu v rokoch 1939-1945 pozri napríklad: E. MACHAJDÍKOVÁ, Slovenské národné múzeum a jeho predchodcovia, s. 15-29; Jarmila STRELKOVÁ, Quo vadis, Slovenské národné múzeum? Múzeum, 1998, roč. 43, č. 1, s. 14-20; Pavol VALACHOVIČ, Slovenské múzeum v rokoch 1940-1948. Múzeum, 1989, roč. 34, č. 1, s. 38-47.

${ }^{86}$ Porovnaj: Miroslav PALÁRIK, Osudy pamiatok pochádzajúcich zo židovského majetku za druhej svetovej vojny, Historický časopis, 2011, roč. 59, č. 3, s. 515-534.

${ }^{87}$ Prírastková kniha bola vedená tak, že pod jedným prírastkovým číslom bolo zapísaných viacero predmetov, preto sa počet prírastkových čísel a počet jednotlivých predmetov odlišoval. 


\section{Záver}

Oblast' múzejníctva bola pre politickú moc na Slovensku v období druhej svetovej vojny v širokom spektre kultúrnych a osvetových inštitúcií na jednom z posledných miest. Súviselo to so skutočnost'ou, že pre šírenie štátnej ideológie a propagandy boli pre štátostranu zaujímavé skôr kultúrne zariadenia navštevované verejnost'ou viac ako boli múzeá (napríklad kiná, knižnice alebo divadlá). Preto sa v zákonoch a nariadeniach ministerstiev objavujú zmienky o múzeách v tomto období len sporadicky a rovnako zriedkavo sa v prejavoch popredných politikov objavovalo slovo múzeum. Najčastejšie sa tak dialo v súvislosti s výchovno-vzdelávacími inštitúciami, resp. s názornost’ou doplnenia vyučovania dejepisu a zemepisu alebo so zákazom vývozu zbierkových predmetov do zahraničia. Predmety v múzeách mali žiakom slúžit' na posilnenie patriotizmu, povzbudzovat' lásku a oddanost' k štátu a národu. Širšie využitie múzejných ústavov na propagandistické ciele bolo v sledovanom období problematické a to vzhl'adom na nízku úroveň vizuálnej stránky väčšiny menších regionálnych múzeí a nezvládanie praktických múzejných činností ich zamestnancami. V tomto smere sa predstavitel'om HSL'S osvedčili vel'ké múzeá v Bratislave a Turčianskom Svätom Martine. Tie poskytovali dostatočné množstvo zbierkových predmetov vhodných dokresl'ovat' prebudovávaný národný príbeh. Po 14. marci 1939 nastali zmeny aj v systéme starostlivosti o pamiatky. Zanikol Štátny referát na ochranu pamiatok na Slovensku a v rámci oblasti múzejníctva vznikol samostatný Zväz slovenských múzeí, ktorý sa mal starat' o pozdvihnutie ich úrovne. Táto úloha bola náročná, ked’že personálne zloženie regionálnych múzeí bolo nedostatočné a viac-menej odkázané na dobrovol'nícku prácu miestnych učitel'ov a kňazov. Na úrovni Zväzu boli prijaté opatrenia smerujúce k zvýšeniu kvality týchto ústavov, ale ich uplatňovanie v praxi zlyhávalo na samotných zamestnancoch. V rámci navrhovaných opatrení mali byt' expozície v slovenských múzeách preinštalované $\mathrm{v}$ duchu moderných muzeologických zásad, prevzatých z nemeckej praxe. Tá akcentovala l'udovýchovný charakter výstav, pri zobrazovaní spoločenského javu zdôrazňovala výdobytky aktuálneho vládnuceho režimu, upozorňovala na rozdiely medzi jednotlivými etnikami. Tým jasne prispievala $\mathrm{k}$ šíreniu ideológie a propagandy. Vo vojnovom čase a provizóriách panujúcich $\mathrm{v}$ danom čase $\mathrm{v}$ múzeách nakoniec prišlo k novému inštalovaniu len v štyroch múzejných pracoviskách. Nemecký výstavnícky trend mohol byt' $v$ slovenských podmienkach aplikovaný len $\mathrm{v}$ takom prípade, že by sa pracovníci sústredili i na dokumentáciu súčasnosti. Zachytili by tak turbulentný vývoj v štáte od roku 1938 a tým uplatnili aktívnu selekciu a dokumentáciu v praxi. Na základe vykonaného výskumu v dvoch najväčších slovenských múzeách možno povedat', že múzejníci túto šancu využili len sčasti. Ich konanie, respektíve v tomto prípade skôr nekonanie, mohlo súvisiet's ich postojom voči rozvíjajúcemu sa nedemokratickému režimu, avšak tento argument je $\mathrm{z}$ hl'adiska muzeologických potrieb nedostatočný, hoci pochopitel'ný. $\mathrm{V}$ prípade bratislavského Slovenského múzea mohli možnosti akvizície predmetov spadajúcich do dokumentácie súčasnosti do vel'kej miery ovplyvnit' okolnosti súvisiace $\mathrm{s}$ hektickými udalost’ami v histórii múzea - jeho vznik v roku 1940 zlúčením troch pracovísk, boj o priestory so štátnymi úradmi, zásah budovy pri leteckých náletoch. Na mieste je nastolenie otázky, či v zmienených ústavoch existovala nejaká jasná koncepcia zbierkotvornej činnosti, respektíve či existovala nejaká štátom vytvorená politika dokumentácie vzniku a vývoja štátu. Doterajšie čiastkové výskumy naznačujú, že koncepcie si pracovníci v múzeách nevytvárali a ak, z rôznych dôvodov (nedostatok finančných prostriedkov, nedostatok odborných zamestnancov, priestorové problémy, opozitný postoj voči režimu) ich nenapíňali. Do zbierkových fondov sa vo vel'kej väčšine prijímali predmety, ktoré boli na ich adresu poukázané zo strany štátnych úradov ako dary, čo by mohlo naznačovat', že štát mal záujem dokumentovat' svoju činnost' $v$ niektorých oblastiach. Vzhl'adom na povahu predmetov išlo o oblasti umenia, kultúry a osvety. V spomenutých múzeách však úplne absentuje dokumentácia zmien $\mathrm{v}$ politickom, spoločenskom a hospodárskom živote, d'alej protižidovských a protirómskych opatrení, o dokumentáciu ktorých nestál ani režim a v danom období ani múzejníci. Naopak, okamžite po skončení druhej svetovej vojny sa začalo s dokumentáciou odbojového hnutia, najmä Slovenského národného povstania, ktoré ako jedna zo zlomových udalostí v národnom príbehu Slovákov v ňom zaujalo významné miesto. 